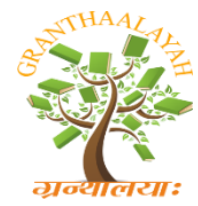
\author{
GRANTHAALAYAH \\ A knowledge Repository
}

INTERNATIONAL JOURNAL OF RESEARCH -

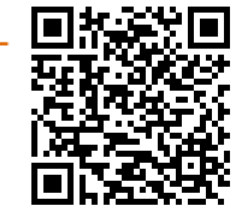

Management

\title{
THE CHALLENGES OF PROFESSIONAL ACCOUNTING PRACTICES IN NIGERIA PRIVATE SECTOR WITH RESPECT TO FINANCIAL FAILURES IN RECENT TIMES
}

\author{
Uchehara Chris Chigo ${ }^{* 1}$, Ogbonna Precious Ijeoma ${ }^{2}$ \\ ${ }^{* 1}$ Ph.D, DBA, FCNA, FFIA, FCIA, FCMA, ACPA, ACTI, Department of Accounting and \\ Finance Crawford University, Ogun state, Nigeria \\ ${ }^{2}$ M.sc, B.sc, MCIA, CPA, CIFC, ACMSP, Financial, Tax, forensic\& Investigative Audit and \\ management Consultants, EZYCHIGO Worldwide consulting company Limited, Ogun State, \\ Nigeria
}

DOI: https://doi.org/10.29121/granthaalayah.v5.i3.2017.1753

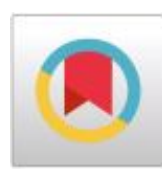

\begin{abstract}
This paper seeks to examine the challenges of professional accounting practices in Nigeria private sector with respect to financial failures in recent times. Survey technique was used and a total sample of one hundred and twenty questionnaires were sampled, purposive sampling technique was used to select one hundred and twenty (120) auditors, accountants, financial managers/directors and other management staff forms the bulk of the entire respondents. Descriptive statistical techniques such as frequency distribution and percentages response analysis were used to analyze data. Results however, revealed that majority are of the opinion that there is yet a level of quality in the financial reports as pertaining to the private sector. It also indicates that the business environment does not permit accountants independence overall. It therefore established the fact that the private sector has not been up to the task of meeting the user's expectation in their financial reports. It thus implies that accountants are party to inadequacies of financial statements in the private sector. It thus implies that professional accounting practices are yet relevant in the financial reports of the private sector. It thus implies that professional accounting practices are identified with certain deficiency that affects disclosure in corporate organizations. This confirmed the depth of corruption and inefficiency in fund management of the private sector. This indicates that the reason for the shortfall in financial reporting is non conformity with professional accounting practices. This indicates that the accountants also contribute to the increasing financial failures of the private sector. This implies that the business environment of the private sector have an influence on the accountants. This confirms the extent at which these qualities reflect in private sector financial reporting. Based on these findings, it was recommended that emphasis on conformity with professional accounting practices. Also, to combat unethical practices by accountants and professional firms, there is a need to educate company executives, policy-makers and the public about the human costs of anti-social and unprofessional practices, as they deprive ordinary Nigerian citizens of their human and social rights and the accounting profession in Nigeria must therefore continue to
\end{abstract}


monitor development in the external and internal reporting environments through its audit, investigations and forensic accounting faculty and respond adequately.

Keywords: Professional Accounting Practices; Private Sector; Financial Failures In Recent Times; Accounting Firms; Accountants; Auditors; Banking Crisis; Professional Misconduct.

Cite This Article: Uchehara Chris Chigo, and Ogbonna Precious Ijeoma. (2017). "THE CHALLENGES OF PROFESSIONAL ACCOUNTING PRACTICES IN NIGERIA PRIVATE SECTOR WITH RESPECT TO FINANCIAL FAILURES IN RECENT TIMES." International Journal of Research - Granthaalayah, 5(3), 45-68.

\section{Introduction}

The professional accounting practices in Nigeria private sector with respect to financial failures in recent times cannot easily be perpetrated without the involvement of intermediaries and professional accountants who assist the perpetrators in converting the proceeds from illicit activities to a legitimate income (Bakre, 2008a; Sikka, 2008a). In a globalised world professional accountants are intermediaries who perform key roles in facilitating financial flows. Professional accountants have cemented their status and privileges on the basis of claims that their expertise enables them to mediate uncertainty and construct independent, objective, true and fair accounts of corporate affairs (Sikka, 2009). It has been argued, however, that such claims are not good indicators of corporate performance, because capitalist economies are inherently prone to crises (Sikka, 2009). Furthermore, the claims of expertise are frequently affected by unexpected corporate collapses, fraud, financial crime and the general crisis of capitalism (Baker, 2007; Sikka et al, 2009).

The world of corruption has attracted some scholarly work which has shown that professional accountants are facilitators of corrupt practices, and that even the 'big four' accounting firms are involved in (Sikka and Hampton, 2005; Bakre, 2006). Christensen, 2006) posited that professional accountants have helped MNCs, wealthy individuals and the political elite to perpetrate corrupt practices. The failure of accounting documents to reveal a more accurate reflection of the financial well-being or ill health of organization especially the private organizations and the collusion of professional accountants in the preparation and validation of those documents, to the failure of the accountancy profession satisfactorily to take account of the private interest in the determination of the future of accounting and auditing practice. High profile corporate collapses and fraud with which accountants have been associated to auditors, executives and directors have prompted searching question to be asked as to the integrity of the professional accountants' involved (Clark et el, 2003).

However, since the birth of the Association of Accountants of Nigeria in 1960, the reputation of the accounting profession has not been well served with regard to the quality of accounting practice. Though the profession has struggled to develop and maintain acceptable position of independence and integrity in financial reporting and auditing ((Okike, 2004), there has, however been a number of criticisms from various groups who have operational interest in financial reporting, including the World Bank and the International Monetary Fund (IMF). The most prominent of these criticisms concern the perceived poor institutional weaknesses in regulation, 
compliance and enforcement of accounting standards and rules. Besides, it is also perceived that there is dearth of professional accountants in the private sector. For instance, the World Bank (2004) observes that there are -500,000 registered companies (with 210 listed on the stock exchange) and 17,500 professional accountants in Nigeria.\| This position, the World Bank further observes, is a significant disparity even taking into account that not all companies may necessarily need a professional accountant and concludes that when non-qualified persons are employed in accounting positions, it can have a negative impact on the quality of financial reports.

The professional accounting standards are hardly complied with in the reporting of organizations financial position. Financial reporting according to Nzotta (2008) is a critical issue which affects the decision making process of various individuals, corporate bodies, investors and policy makers. Glautier and Underdown (2001) stated that the essence of financial reporting is to communicate information about the resources held by an entity and the performances of the reporting entity, useful to those having the prerogative right to such information. According to Nzotta (2008) the financial reports is naturally meant to assist users in evaluating the past and present performance of the organization and its ability to maximize the wealth of the shareholders, making the decision whether to keep investing in such business or decline in their investment into such business. In the private sector, financial reporting is a means to assessing the ability of the organization to create value and objective assessment of the value created overtime (Glautier and Underdown 2001).

Belkaoui (2002) posited that the qualities of financial reports is very important reflecting as relevance, understandability, reliability, completeness, objectivity, timeliness and comparability; while Best, (2009) opined that the fundamental qualitative characteristics (that is, relevance and faithful representation) are most important and determine the context of financial reporting information, been the true representation of professional accounting practice. Bakre (2007) posit that contrary to the notion that it is only the public service that is heavily infested with corruption and inefficiency in fund management (as reflected in the financial reporting), the tide has since changed in Nigeria, as the private sector also has been caught up in identical unethical muddle.

According to Bakare, (2011), mismanagement of finance in private organizations which is as a result of corruptible practices has been rampart. This has led to false declaration in the financial reporting of the organizations having its root in non-conformity with professional accounting practices. Private sector mismanagement of fund manifesting in form of corruption, which focus on intentional acts committed, with a view to giving, accepting and soliciting an advantage inconsistent with official duty, has of recent become a cancer which attacks the structure of the private sectors, taking place in the form of bribery, kickbacks, commissions, related transactions, financial statement re-engineering, or other benefits without leaving any trace in the official records (Essia, 2005), the consequence been financial failure of the private sector businesses.

As indicated by Agbetunde, (2010) the accountants who maintains the financial records in the organization and also been the ones at the helm of financial reporting are not to be left out in the increasing financial failure of the private sector. Bakre (2007) ascertained that the business environment the accountants find themselves in this recent time is complex. As ascertained by 
him, the complexity of the business environment serves as a threat to the accountants declaration of high quality financial reporting in terms of its strict confidentiality, integrity, transparency, accountability, competence, loyalty, honesty, anonymity, impartiality, neutrality and truth, fairness, professional independence/freedom and more (Bakre, 2007).

A business environment riddled with corruptible practices poses a lot of challenges to the accountant abiding by the established professional accounting practices in financial reporting. As mentioned by Bekele and Zeleke, (2008), most directors of companies operating in corrupt environments cook the books to hoodwink the investors and amass wealth to themselves to the detriment of the resource owners. These corrupt practices invariably militate against the work of accountants limiting the reliability and relevance of financial report and resulting in a loss of confidence in the accounting profession and the established professional accounting practices. While Mishra, Wilson and Williams, (2009) mentioned that accounting professionals in general, increasingly use their expertise to conceal and promote corruptible practices in the financial reporting of the private sector organizations, to derive private economic gain for themselves and for their clients to the detriment of the public interest they claim to be protecting, culminating in the financial failure of the organization at the long run.

Albrecht and Sack (2000) posit that despite accountant's claims to be acting in a professional manner, accountants have been implicated in facilitating the flow of private funds stolen from private organization inclusive of false declaration through diverse structures. Adeyeye, Adeyemi and Otusanya (2010) asserted that this period has been characterized by series of private sector financial failures, ethical negligence and accounting scandals in the country, while the various collapses of the private sector have led to increased scrutiny of deficiencies in the professional accounting practices reflected as poor financial reporting process and corporate disclosure requirements of corporate organizations. The accounting profession in relation with professional accounting practices in the Nigeria private sector, has been the subject of severe criticism in recent times, due to financial misrepresentation of many private sector businesses; more so following the extensive corporate collapse such as the financial statement fraud involving Cadbury Plc., Daewoo Group, Innovates Securities Ltd in Nigeria, Power Holding Company of Nigeria, coupled with the fraudulent financial reporting of financial institutions such as the Oceanic Bank Plc, Afribank Plc and Intercontinental bank Plc with the dire consequences on the shareholders and the bank depositors. As it were, much concern has been on accounting practices and according to Sanusi (2010), the Nigeria banking sector has experienced several failures while owners and managers of these financial institutions constantly devised means by which the banks were defrauded.

For instance, In Nigeria the spate of corporate failures witnessed in the financial sector in the early 1990s brought auditors into sharp focus and caused the Nigerian public to question the role of accountants and auditors (Okike, 2004; Bakre, 2007; Ajibolade, 2008). Furthermore, the investigations launched by the regulators and other stakeholders into the cases of distress and disclosure revealed that accountants and auditors were implicated (NDIC, 1995). With the recent banking crisis in Nigeria, members of the auditing profession in Nigeria are once again in the limelight, as the banking crisis and the revelation of unethical practices by bank executives and board members has raised many questions about the ethical standards of the accounting profession and about the integrity of financial reports issued by professional accountants 
(ThisDay, 9 December 2009). The question has been raised as a result of the failure on the part of accountants and auditors to alert regulators when they have discovered fraud and other irregularities in company records (Bakre, 2007; Ajibolade, 2008; Okike, 2009; Neu et al, 2010). In respect of the banking crisis, attention has focused on the role of accountants and auditors who have been involved. Accountants and auditors may be expected to report financial irregularities in company accounts by enhancing transparency and accountability and by developing techniques for fraud detection ie forensic audit and investigation, wish is the current practice in developed countries all over the world Uchehara 2016. However, an emerging body of literature argues that accounting professionals have increasingly used their expertise to conceal and promote anti-social practices (Sikka, 2008a; US Senate Permanent SubCommittee on Investigations, 2005; Bakre 2007). For example, Akintola Williams and Deloitte (AWD) was indicted for facilitating the falsification of the accounts of Afribank Plc and for deliberately overstating the profits of Cadbury Nigeria Plc. It has been reported that between 1990 and 1994 the Nigerian economy lost more than N6 billion ( $\$ 42.9$ million) to fraud within the banking sector alone (Bakre, 2007).

Consequently, Nzotta, (2008) posit that financial failure of private organization has had a negative and cumulative impact on the perceived credibility of financial reporting of many private sector businesses. The private sector has fallen short-off expectations in this respect experiencing fraud and mismanagement of funds leading to their financial failure. This financial failure concern, in which deficiencies of financial reporting and corporate disclosure have figured prominently, is now at the forefront of public debate about the accounting profession and its compliance with the professional accounting practices in their financial reporting (IFAC, 2003).

However, the need of accounting in all human endeavours cannot be over emphasized, more in the private sector where investments are made by the public in the running of the entities with an expectation of earning a return at due date. Maintenance of accounting records which involves documenting all transactions of the private sector business, inclusive of assets, liabilities and capital (liquidity) therefore becomes imminent. Additionally, for the public interest to be reawakened in the accounting profession, the professional accounting practices needs be revisited and complied with in financial reporting. This would ensure high quality accounting information reporting such that reflects transparency, facilitating the mobilization of investment, and fostering investor confidence, promoting financial stability of organizations with issues of financial failure well curbed and the public investment in private sector safe. Likewise, this would curb corruption and mismanagement of resources in the private sector (Agbetunde, 2010). In order to fully understand corrupt and fraudulent financial practices in Nigeria, it is necessary to explore the challenges of professional accounting practices in Nigeria private sector with respect to financial failures in recent times.

\section{Literature Review}

The involvement and culpability of professional accountants in unethical practices and conflicts of interest have long been documented by critical accounting scholars in developed and developing countries (García-Benau and Humphrey, 1992; McHugh and Stamp, 1992; Sikka and Willmott, 1995; Cousins et al, 2000; Mitchell et al, 2001; Bakre, 2007; Sikka, 2009; Sikka et al, 
2009; Gyénin-Paracini and Gendron, 2010). Recent time has witnessed the collapse of a number of corporate giants, such as Enron, WorldCom, and Arthur Andersen in the USA and BCCI in the UK. The Nigerian business community is also plagued with ethical problems associated with business collapse (Bakre, 2007). Unethical business behaviour and corporate scandals involving large companies, such as African Petroleum Plc, Cadbury Nigeria Plc and Lever Brothers Plc, have been reported (Bakre, 2007; Ajibolade, 2008).

Enron, the Texas-based energy trading company, caused one of the major scandals which shook up the auditing profession. Enron caused a crisis in respect of the confidence placed in auditors and the reliability of financial reporting. Arthur Andersen, Enron's accountant, was accused of a conflict of interest which led to it being accused of professional misconduct and other unethical accounting practices (Mitchell and Sikka, 2002). The quality of the audit and the independence of the auditors were questionable because Arthur Andersen received not just audit fees but fees for non-audit services. For example, it earned $\$ 55$ million for non-audit services and there were regular exchanges of employees within Enron from Arthur Andersen, thereby affecting the independence of the auditors and causing a conflict of interest.

The professional accounting has been the subject of severe criticism in recent times following the extensive corporate collapse such as Enron in the United States of America, and the financial statement fraud involving Cadbury Plc in Nigeria. As noted by Emenyonu (2007), corruption is a universal human problem as it exists in every country of the world.ll However, there are countries where corruption is so pervasive that it makes impossible any effort at progress. In countries where corruption is rife, accountability processes could be weak and any attempt to make progress in development of accounting profession/practice under such circumstances is likely to be frustrated. This assertion buttresses the view of Wallace (1992) that in a highly corrupt society, such as Nigeria, auditing may not be allowed to thrive because people are dishonest, suspicious of each other and violent.

Professional accountant may be expected to combat anti-social financial practices by enhancing transparency and accountability and by developing techniques for fraud detection by institutionalizing forensic and investigative audit practice as obtainable in most of developed countries of the world Uchehara( 2016 ) . However, a body of literature has argued that accounting and finance professionals increasingly use their expertise to conceal and promote anti-social practices (US Senate Permanent Sub Committee on Investigations, 2005; Bakre 2007; Sikka, 2008; Otusanya, 2010). Accounting technologies, such as transfer pricing, have also become central to masking and shifting the proceeds of corrupt activities (see Baker, 2005; Pak, 2006; AAPPG, 2006; Sikka and Willmott, 2010). Thus, professionals use these technologies and structures to derive private economic gain for themselves and for their clients to the detriment of the public interest they claim to be protecting (US Senate Sub-Committee on Investigations, 2006; Bakre, 2007; Sikka, 2008; Otusanya and Lauwo, 2010).

Thus, despite their claims to be acting in a professional manner, accountants have been implicated in facilitating the flow of public funds stolen from developing countries through structures in Western countries (AAPPG, 2006). Offshore tax havens providing secrecy and low regulation have been identified as key vehicles for the movement of 'hot' money (Palan, 2002; Tax Justice Network, 2006; Christian Aid, 2005; Palan et al, 2010). As an investigation by the 
US Senate Sub-Committee on Investigations (2006) revealed that financial professionals often use offshore tax haven secrecy laws and practices that limit corporate, bank and financial disclosures as a "black box to hide assets and transactions from tax authority, regulators and law enforcement. The role of accountants in perpetrating corrupt and fraudulent practices seems to deviate from and contradict their primary role as external watchdogs of shareholders' wealth and as protectors of the public interest.

In recent times accountants have been accused of being involved in what has been described as harmful and corrupt and fraudulent practices purely for the sake of high fees (Otusanya and Lauwo, 2010). In recent years there have been many studies which have examined the role of the accounting profession (both accountants and accounting firms) in cases of financial crime (such as fraud, corruption, tax evasion and tax avoidance) at the corporate, political directorate and public service levels (Sikka, 2005, 2008a; the US Senate Sub-Committee on Investigations, 2005, 2006; Mitchell et al, 1998; Bakre, 2006, 2007; Otusanya, 2010). Despite the fact that the major accountancy firms are some of the world's biggest corporations (Sikka, 2008a), it has been shown that, in order to increase their profits, accountants sell tax avoidance schemes, facilitate bribery and corruption, and facilitate the setting up of shell companies, complex corporate structures and a web of offshore companies and offshore trusts.

Although professional accountants have helped companies and wealthy individuals to evade taxes and effect illegal capital flight, they have denied their involvement in such corrupt practices, even though subsequent investigations have proved otherwise (Bakre, 2006, 2007, 2008; Sikka, 2008a). PricewaterhouseCoopers, for example, agreed to pay the USA more than $\$ 2$ million to settle allegations that it had (with IBM) solicited and provided improper payment and other things of value in respect of technology contracts with government agencies (US Justice Department, 2007). KPMG was also accused of not doing enough to flag improprieties in their client's (Siemens) books (Wall Street Journal, 2 May 2007). In 2004 KPMG was accused of failing to report an alleged bribe paid by BAE, UK's largest arms company, to secure an arms contract (The Guardian, 8 March 2004).

In addition, the legal profession has also been identified as another professional group promoting in various ways the ever-increasing patronage of the tax avoidance industry (the US SubCommittee on Investigations, 2003, 2006; Palan et al, 2010). It has been shown that lawyers have acted as facilitators of antisocial practices (Lankhorst and Nelen, 2004; Meddleton and Levi, 2004). Thus, lawyers have assisted in establishing offshore structures, drafting financial instruments and providing legal opinions on the legality of offshore transactions (the US Senate Sub-Committee on Investigations, 2006), and have acted as nominee directors and shareholders (Tax Justice Network, 2005). A number of studies have cited cases where lawyers have been involved in anti-social practices ranging from acting as 'messenger boy' for their clients to being involved in conflicts of interest (see Spronken, 2001; Lankhorst and Nelen, 2004). The US Senate Sub-Committee on Investigation Report on law firms and tax haven abuses confirmed the involvement of lawyers in anti-social practices when it reported that: 'Apart from giving legal advice, the lawyers helped identify and negotiate with offshore service providers to establish and manage offshore entities, devised ways to move assets offshore and drafted the paperwork needed to implement these transactions for their clients (US Senate SubCommittee on Investigations, 2006) 
Furthermore, banks and financial intermediaries also play a role in facilitating corrupt and fraudulent practices practices by serving as the channel through which illicit funds or 'dirty' money flow around the World. Although banks are major vehicles for economic development, as they provide funds for both the private and public sectors in an economy, they have been identified as facilitators of corrupt and fraudulent practices practices (Oxfam, 2000).

A number of recent studies have questioned the value of company audits, auditor independence, the quality of audit work, economic incentives for good audits and the knowledge base of auditors (Sikka, 2009; Sikka et al, 2009). These studies have argued that the issuance of audit reports is subject to organisational and regulatory politics, that fee dependency impairs claims of independence and has the capacity to silence auditors, and that the intensification of financial capitalism poses questions about the knowledge base of auditors (Sikka, 2009; Sikka et al, 2009). A study by Sikka (2009) has shown that distressed financial enterprises in the UK, USA, Germany, Iceland, The Netherlands, France and Switzerland have received unqualified audit opinions on their financial statements published immediately prior to the public declaration of their financial difficulties; and that these opinions were provided by the big four accounting firms, namely PricewaterhouseCoopers, Deloitte and Touche, Ernst \& Young, and KPMG.

A number of studies have documented the role of accountants and auditors in unethical practices and other professional misconduct in the public service and in the private (corporate) sector in Nigeria (Adeyemi, 2004; Bakre, 2007; Ajibolade, 2008). A study by Bakre (2007) has documented various cases in which accountants and external auditors in collaboration with the management and directors of companies falsified and deliberately overstated company accounts. Investigations into the financial report of Afribank implicated Akintola Williams \& Deloitte in facilitating an overstatement of the bank's account by the management (Bakre, 2007). Other Nigerian cases have also been documented in which a number of professional accounting firms were involved in, and indicted for, anti-social practices in conflict with their professional claims to be acting in the public interest; and it was suggested that the matter needed further investigation (Bakre, 2007).

The causes of audit failure have been attributed to poor audit reporting resulting from sloppy accounting, inadequate regulation, crony capitalism, multiple regulations, and economic and political factors influencing the incentives of managers and auditors (Dabor and Adeyemi, 2009; Sikka 2009). It has also been stated that, where there is a separation of ownership from the control of a business, there is a tendency for managers of companies to engage in fraudulent financial reporting in order to maximise their own personal welfare to the detriment of the interests of the users of financial statements, the investing public and bank depositors (Sikka et al, 2009; Dabor and Adeyemi, 2009). Bank failures have also been associated with endogenous forces, lack of scruple, lack of knowledge and information, poor judgement, speculation, greed and fraud.

\section{Materials and Methods}

Quantitative and descriptive survey research design was adopted for this research. Quantitative technique will be used for this project as it can provide a much wider coverage and it is fast and economical. Also, it offers convenience and can be analyzed without wasting much time; results 
generated will be detailed and would represent the larger population. The study selects three (3) private firms/companies in Lagos State (First Bank Plc, Cadbury Plc and KPMG). Purposive sampling technique was employed to select one hundred and twenty (120) auditors, accountants, financial managers/director and other management staff forms the bulk of the entire respondents of the study. The number was considered adequate and representative enough to inform this sample as a result of the wild spread of the organization and also respondents are considered knowledgeable enough to be able to supply credible information that will help the completion of this study. According to rules of thumb, Roscoe (1975) suggest that sample size which is more than 30 and less than 500 are appropriate for the research. The research instrument adopted is structured questionnaire which was used to generate information from the respondents on the phenomenon under study. Descriptive statistics of frequency percentage and tables was used to analyse the data at 0.05 alpha level of significance using the Statistical Package for Social Sciences (SPSS).

\section{Results and Discussion}

\section{Respondent's Demographic Information}

The study investigated the profile of the respondents of the study. The percentage of the respondents that belong to each category of the characteristics was analysed. The results are presented in Table 1-5 (see appendix).

From table 1 (see appendix) the table shows that 69(57.5\%), are male respondents and $51(42.5 \%)$ are female respondents in which the male gender constitutes the highest percent. It implies that the interest of both gender categories was considered in this study without bias.

From table 2 (see appendix)the table shows that 25(20.8\%) of the respondents fall within the age group of 18-30years, and $61(50.8 \%)$ of the respondent fall within the age group of 30-40years, $23(19.2 \%)$ of the respondent fall within the age group of 51years and above, $13(7.4 \%)$ of the respondent fall within the age bracket of 41-50years.it indicates that respondents were not minor and that their opinion could be relied on to be valid.

From table 3 (see appendix) the table shows that 28(23.3\%) of the respondents have HND educational qualification, 66(55.0\%) of the respondents have B.Sc/B.Tech/B.Eng.educational qualification, and $26(21.7 \%)$ of the respondents have M.Sc/M.Tech/ M.Eng.educational qualification. It could be infered that respondents have educational background which informs on their expreessed opinion.

From table 4 (see appendix) the table above shows that $27(22.5 \%$ ) of the respondents have ICAN/ANAN as their professional qualification, 43(35.8\%) of the respondents have ACCAas their professional qualification, and $17(14.2 \%)$ of the respondents have CIBN as their professional qualification. It is evidents that respondents are professionally qualified to express a valid opinion on the phenomenon.

From table 5 (see appendix) the table shows that $44(36.7 \%)$ of the respondents havehad below 10 yearsworking Experience, 76(63.3\%) of the respondents have had within the range of 11-20 
years working Experience.it therefore means respondents opinion been informed by their years of working experience, could be relied on.

\section{The Challenges of Professional Accounting Practices in Nigeria Private Sector With Respect To Financial Failures in Recent Times}

From table 6 (see appendix) responses to the research statement "The private sectors in Nigeria has been identified with high quality financial reporting" are interpreted thus; $(21.7 \%)$ of the respondents strongly agrees, and (31.7\%) agrees and (14.2\%) not sure, (16.7\%) disagreed, $(15.8 \%)$ strongly disagreed. It conotes majority are of the opinion that there is yet a level of quality in the financial report as pertaining to the private sector.

From table 7 (see appendix) responses to the research statement "The business environment as obtainable in the private sector allows for accountants independence in financial reporting" are interpreted thus; $(6.7 \%)$ of the respondents strongly agrees, and (7.5\%) agrees and (25.0\%) not sure, $(40.0 \%)$ disagreed, $(20.8 \%)$ strongly disagreed. It indicates that the business environment does not permit accountants independence overall.

From table 8 (see appendix)responses to the research statement "The private sector have fallen short-off expectations in financial reporting, experiencing fraud and mismanagement of funds leading to their financial failure" are interpreted thus; $(21.7 \%)$ of the respondents strongly agrees, and (28.3\%) agrees and(9.2\%)not sure, $(20.8 \%)$ disagreed, $(20.0 \%)$ strongly disagreed. It therefore established the fact that the private sector has not been up to the task of meeting the users expectation in their financial report.

From table 9 (see appendix) responses to the research statement "Accountants are party to some inadequacies in the financial statement of private organization" are interpreted thus; $(76.7 \%)$ of the respondents strongly agrees, and also, (23.3\%) agrees. It thus implies that accountatants are party to inadequacies of finanacial statements in the private sector.

From table 10 (see appendix) response to the research statement "Poor financial reporting means false financial representation of organization to the public" is interpreted thus; $(100.0 \%)$ of the respondents strongly agrees. This shows the essentiality of the finanacial reporting.

From table 11 (see appendix) responses to the research statement "The financial reporting of private sector is based on professional accounting practices" are interpreted thus; $(21.7 \%)$ of the respondents strongly agrees, and (30.0\%) agrees and(5.8\%)not sure, $(27.5 \%)$ disagreed, (15.0\%) strongly disagreed. It thus implies that professional accounting practices are yet relevant in the financial report of the private sector.

From table 12 (see appendix) responses to the research statement "Deficiencies in the professional accounting practices is the reason for poor financial reporting and disclosure of corporate organizations" are interpreted thus; $(33.3 \%)$ of the respondents strongly agrees, and (27.5\%) agrees and(10.0\%)not sure, (21.7\%) disagreed, (7.5\%) strongly disagreed. It thus implies that professional accounting practices are identified with certain deficiency that affect disclosure in corporate organizations. 
From table 13 (see appendix) responses to the research statement "The private sector of recent has been heavily infested with corruption and inefficiency in fund management" are interpreted thus; (13.3\%) of the respondents strongly agrees, and (15.8\%) agrees and(20.8\%)not sure, (29.2\%) disagreed, (20.8\%) strongly disagreed. This confimed the depth of corruption and inefficiency in fund management of the private sector.

From table 14 (see appendix) responses to the research statement "False declaration in the financial reporting of the private organizations have its root in non-conformity with professional accounting practices" are interpreted thus; (30.8\%) of the respondents strongly agrees, and $(51.7 \%)$ agrees and(7.5\%)not sure, $(5.0 \%)$ disagreed, while $(5.0 \%)$ strongly disagreed. This indicates that the reason for the shortfall in finacial reporting is non conformity withprofessional accounting practices.

From table 15 (see appendix) responses to the research statement "The accountants at the helm of financial reporting are not left out in the increasing financial failure of the private sector" are interpreted thus; $(25.8 \%)$ of the respondents strongly agrees, and (42.5\%) agrees and(5.0\%)not sure, $(10.8 \%)$ disagreed, while $(15.8 \%)$ strongly disagreed. This indicates that the accountatants also contribute to theincreasing financial failure of the private sector.

From table 16 (see appendix) responses to the research statement "The complexity of the business environment serves as a threat to the accountants declaration of high quality financial reporting" are interpreted thus; (48.3\%) of the respondents strongly agrees, and $(36.7 \%)$ agrees and $(5.8 \%)$ not sure, $(5.0 \%)$ disagreed, while $(4.2 \%)$ strongly disagreed. This implies that the business environment of the private sector have an influence on the accountants.

From table 17 (see appendix) responses to the research statement "Corrupt practices militate against the work of accountants in financial report resulting in a loss of confidence in professional accounting practices" are interpreted thus; $(78.3 \%)$ of the respondents strongly agrees, and $(21.7 \%)$ agrees. This implies that corrupt practices truly affects the role of the accountants in the private sector.

From table 18 (see appendix) response to the research statement "Relevance, understandability, reliability, completeness, objectivity, timeliness and comparability are most important in the context of financial reporting information of private sector" is interpreted thus; $(100.0 \%)$ of the respondents strongly agrees. This indicates the feature expected in thefinancial reporting information of private sector.

From table 19 (see appendix) responses to the research statement "A business environment riddled with corruptible practices poses a lot of challenges to accountant conforming to professional accounting practices in financial reporting" are interpreted thus; $(44.2 \%)$ of the respondents strongly agrees, and (43.3\%) agrees, $(4.2 \%)$ not sure while $(8.3 \%)$ disagrees. This implies that business environment in which the accountants operates influence on his delivery.

From table 20 (see appendix) responses to the research statement "Transparency, accountability, honesty, neutrality and truth, fairness, professional independence reflect in private sector financial reporting" are interpreted thus; $(12.5 \%)$ of the respondents strongly agrees, and $(25.0 \%)$ 
agrees, (16.7\%) not sure while (25.0\%) disagrees, and (20.8\%) strongly disagree. This confirms the extent at which these quality reflect inprivate sector financial reporting.

\section{Conclusion/ Recommendation}

The paper considered the challenges of professional accounting practices in Nigeria private sector with respect to financial failures in recent times, in order to understand why professional accountants prioritise organisational rather than personal and professional values. It was discovered from the finding that one of the challenges of Professional accountants have been implicated in various corrupt and fraudulent practices because there are institutional pressures to increase profits and because organisational and socio-political structures prioritise the best interests of clients rather than the best interests of the public. Thus, there is evidence to show that huge sums of public money have been looted and laundered through a number of accounts in Western countries and within local banks (Otusanya, 2010).

The evidence shows that local financial institutions and Western banks have played host to most of the funds stolen and siphoned from the Nigerian Treasury by the political elite. Thus professional financial intermediaries (such as accountants) have acted as facilitators of corrupt practices, and became slaves to the politicians in perpetrating the looting activities of the political elite, possibly for monetary gain, and contrary to the ethical standards of their professions and their claims of protecting the public interest.

According to (Sikka, 2008a), the claims of professional accountants to be ethical, transparent and knowledgeable is a mere strategy for cementing their social power and for showing that they are acting in the public interest (Sikka, 2008a). The paper has argued that the anti-social financial practices of the economic and political elite and MNCs have been facilitated by professional accountants, in conflict with their professional claim to be serving the public interest. Also, the evidence shows that auditors lack their acclaimed expertise to conduct an independent and objective reporting of corporate affairs. An inquiry into the activities and involvement of professional accountants in the falsification of company accounts in the recent banking crisis in Nigeria would help to draw public attention to the unethical practices of professional accountants and the shortcomings of current practices in Nigeria. Although audit reports are the public and visible evidence of an audit, little is known about the processes and organisational values associated with their production (Sikka, 2009). As has been argued in this paper, in the pursuit of profit accountancy firms exert time and budget constraints and place pressure on audit personnel with the result that some have responded by adopting irregular practices and have even resorted to the practice of falsifying audit reports (Bakre, 2007).

Although it is common practice for companies and their directors to select and remunerate auditors, it has been argued that such an audit model is fundamentally flawed and cannot deliver an independent or searching audit (Sikka et al, 2009). The flaws are further compounded by permitting auditors to have a direct economic interest in corporate transactions through the sale of accounting services. There is evidence to show that the commercialization of professional firms enables them to act as a 'watchdog' on profits and, on occasions, appease and even collude with directors (Bakre, 2007; Sikka et al, 2009). Their professional independence is indeed compromised because auditors are dependent on executive directors for their nomination, 
appointment and the determination of their fees, and, as a consequence, they cannot easily go against the interests of executive directors. To strengthen corporate reporting and auditing there should be corporate democracy in that stakeholders should have the power to determine who should be the auditor and how the auditor is to be remunerated. The evidence shows that, despite acclaimed codes of ethics and claims to be promoting and protecting the public interest, there have been many reported cases of professional misconduct by accountants and auditors, and, as a result, such 'professionals' have adopted a compromising stance (see Bakre, 2007). The resignation of AWD as external auditors of Cadbury Nigeria Plc may imply that AWD did accept the charges of collusion with the management, even though it claimed that it had resigned to protect the best interest of shareholders and for reasons of corporate governance.

The involvement of accountancy firms in corrupt and fraudulent practices in Nigeria has not been exposed or sanctioned by their professional bodies but by regulators (in the case of the recent banking crisis) and by whistleblowers (in the case of Afribank and Cadbury Nigeria Plc). Professionals have been implicated in unethical practices, but their role in such practices has rarely been investigated. Although section 368 of the Companies and Allied Matters Act 1990 creates civil liability for negligent auditors, liability is yet to be imposed. It has been argued that the compromising stance of the self- regulatory professional bodies in sanctioning their erring members has been further facilitated by the non-interference attitude which has usually been adopted by the Nigerian government (Bakre, 2007). The Nigerian accounting professional bodies should ensure that they enforce and maintain their acclaimed duty to see that their members exercise due diligence and act in a morally and ethically upright manner and in the best interests of their clients and of the Nigerian public as a whole financial reporting been a critical issue affecting virtually every of the decision making of various users (individuals, corporate bodies, investors and policy makers) cannot be jettisoned in the private sector. It is germane, as it is the means of communicating to the user the financial performance and worth of the organization, informing on the users decision making as regards their investment into such endeavour. However, issues such as mismanagement of funds and corruptible practices in the private sector has limited the efficacy of the financial reporting, having its bases in non-conformity with professional accounting practices by accountants in the private sector. This has brought about the financial failure of some private organizations such as Cadbury Nig.Plc., power holding company, some financial institution and many more.

The need for accounting in all human endeavors cannot be over emphasized, more in the private sector where investments are made by the public in the running of the entities with an expectation of earning a return at due date. This therefore calls for the need to ensure high quality accounting information reporting such that reflects transparency, facilitating the mobilization of investment, and fostering investor confidence, promoting financial stability of organizations with issues of financial failure well curbed and the public investment in private sector safe. On the basis of findings of the study, the following are recommended:

1) Emphasis on conformity with professional accounting practices

2) More orientation by accounting professional bodies for the accountants on how to manage the complex business environment

3) Independence of the accountants to be mandated in the private sector

4) Remuneration of the accountant should be such that motivate his commitment to truth and fairness in financial reporting 
5) Organizations to design modalities that allow for checks and balances on the role of the accountant from time to time.

6) To combat unethical practices by accountants and professional firms there is a need to educate company executives, policy-makers and the public about the human costs of antisocial and unprofessional practices, as they deprive ordinary Nigerian citizens of their human and social rights.

7) The accounting profession in Nigeria must therefore continue to monitor development in the external and internal reporting environments through its audit, investigations and forensic accounting faculty and respond adequately.

\section{References}

[1] Adeyemi S. B. (2004) 'Minimisation of Financial crime: The Role of the Accountant', Student Accountant Journal, 1: 7-13.

[2] Adeyeye GB, Adeyemi SB, Otusanya OJ (2010). Ethical challenges of practicing accountants in Nigeria. Nigerian J. Manage. Stud., 10(2): (290-326).

[3] Agbetunde, L. A. (2010). Principles \& practice of personal income tax, 2nd ed. Ogun: Feetal Consulting Publishers, Ogun State, Nigeria.

[4] Akindele, S. T. (2005) 'A Critical Analysis of Corruption and its Problems in Nigeria', Anthropologist, 7 (1): 7-18.

[5] Albrecht WS, Sack RJ (2000). Accounting Education: Charting the course through a perilous future, Acc. Edu. Series No. 16, American Acc. Ass., Sarasota, FL.

[6] Amundsen, I. (2006) 'Political Corruption', U4 Issue 6, CMI, Chr. Michels Institute.

[7] Bakare, A.S. (2011). The impact of interest rates policy on the performances of manufacturing sub-sector in Nigeria. Prime Journal of Business Administration and Management 1(8).

[8] Baker, R. W. (2005) Capitalism's Achilles Hell: Dirty Money and How to Renew the Free Market System, New Jersey: John Wiley \& Sons.

[9] Bakre OM (2007). The unethical practices of accountants and auditors and the compromising stance of professional bodies in the corporate world: evidence from Nigeria. Accting. Forum, 31: 277-303.

[10] Bakre, O. M. (2006) 'Tax Avoidance, Capital Flight and Poverty in Nigeria: The Unpatriotic Collaboration of the Elite, the Multinational Corporations and the Accountants: Some Evidence', Being Paper Presented at the 2006 University of Essex Tax Workshop, Essex Business School, University of Essex, UK, July.

[11] Bakre, O. M. (2007) 'Money Laundering and Trans-Organised Crime in Nigeria: Collaboration of Local and Foreign Capitalist Elites', School of Accounting, Finance and Management Working Paper 07/03, University of Essex, UK.Accountancy Business and the Public Interest 2011

[12] Bakre, O. M. (2007) 'The Unethical Practices of Accountants and Auditors and the Compromising Stance of Professional Bodies in the Corporate World Evidence from Corporate Nigeria', Accounting Forum, 31(3): 277-303.

[13] Bakre, O. M. (2008a) 'Looting by the Ruling Elite, Multinational Corporations and the Accountants: The Genesis of Indebtedness, Poverty and Underdevelopment in Nigeria', paper presented at the 2008 University of Essex Tax Workshop, Essex Business School, University of Essex, UK, July.

[14] Bakre, O. M. (2008b) 'International Financial Corporation's Neo-Liberal Privatisation Policy meets Privatisation drive of the new Post Military Nigerian Neo Colonial Capitalist Elites', paper presented at the Centre for Global Accountability, Essex Business School, University of Essex, UK. 
[15] Bekele, E rk. W Zeleke, (2008). 'Factors that Affect the Long-term Survival of Micro, Small and Medium Enterprises in Ethiopia,' South African Journal of Economics, 76 (3), 1-33.

[16] Chevrier, E. (2004) 'The French Government's Will to fight Organised Crime and Clean Up the Legal Professions: The Awkward Compromise between Professional Secrecy and Mandatory Reporting', Crime, Law and Social Change, 42 (2-3): 189-200.

[17] Christensen, J. (2006) 'Follow the Money: How Tax Havens Facilitate Dirty Money Flows and Distort Global Markets', Tax Justice Network, September, 2006.

[18] Elliott, K. A. (1997) 'Corruption as an International Policy Problem: Overview and Recommendations', in Kimberly Ann Elliott (ed) Corruption and Global Economy, Institute for International Economics, pp. 175-233.

[19] Essia, U. (2005). Stimulating private sector development in Nigeria: The CISP approach.Union Digest $91 \& 2$.

[20] Fawehinmi, G. (2004) 'Probing Corruption in Nigeria', Nigeria World, Online. Available at: http://nigeriaworld.com/feature/publication/fawehinmi/012604.html (accessed 22 December 2007).Accountancy Business and the Public Interest 2011

[21] González de Aragón, A. (2004) 'The Benefits of INTOSAI to Supreme Audit Institutions', INTOSAI: 50 Years (1953-2003) - A Special Publication of the International Organisation of Supreme Audit Institutions', 122-130 Online. Available at: http://www.intosai.org/blueline/upload/4124efestschrift.pdf(accessed 23 July 2008).

[22] Grey, C. (1998) 'On Being a Professional in a 'Big Six' Firm', Accounting, Organisation and Society, 23 (5/6): 569-587.

[23] Gruner, J. (1999) 'Is it the Professional Duty of An Accountant to Expose Corruption', The Nigerian Accountant, 32 (2): 37-38.

[24] Gunz, H. P. and Gunz, S. P. (2006) 'Professional Ethics in Formal Organisations', in Royston Greenwood and Roy Suddaby (eds) Professional Service Firm: Research in the Sociology of Organisations, 24: 257-281.

[25] Hanlon, G. (1994) The Commercialisation of Accountancy: Flexible Accumulation and the Transformation of Service Class, New York: St Martin's Press.

[26] Hanlon, G. (1996) 'Casino Capitalism' and the Rise of the 'Commercialised' Services Class An Examination of Accountants', Critical Perspectives on Accounting, 7 (3): 339-363.

[27] Hoa, Y. and Johnston, M. (2002) 'Corruption and the Future of Economic Reform in China', in Arnold, J. Heidenheimer and Michael Johnston (eds) Political Corruption: Concept and Contexts, New Jersey: Transaction Publisher, New Brunswick.

[28] Ikubaje, J. (2005) 'Nigeria: Anti-Corruption Initiatives and the Constitution. AfricaFiles, 2 (2). Online. Available at http://www.africafiles.org/atissueezine.asp?issue=issue2\#art1, (accessed 15 July 2008).

[29] International Monetary Fund (2001) 'Financial System Abuse, Financial Crime and Money Laundering', Background Paper, Washington, DC: International Monetary Fund Online. Available at: http://www.imf.org/external/np/ml/2001.pdf (accessed 10 July 2008).

[30] Iyoha, F. O. and Oyerinde, D. (2010) 'Accounting Infrastructure and Accountability in the Management of Public Expenditure in Developing Countries: A Focus on Nigeria', Critical Perspectives on Accounting, 21 (5): 361-373.Accountancy Business and the Public Interest 2011

[31] Kaufmann, D. and Dininio, P. (2006) 'Corruption: A Key Challenge for Development', in R. Stapenhurst, N. Johnston and R. Pelizzo (eds) The Role of the Parliament in Curbing Corruption, World Bank Publication: 13-25.

[32] Klitgaard, R. (2000) 'Subverting Corruption', Finance and Development, June, Online. Available at: http://www.imf.org/External/Pubs/Ft/Fandd/2000/06/pdf/klitgaar.pdf (accessed 8 September 2008).

[33] Lankhorst, F. and Nelen, H. (2004) 'Professional Services and Organised Crime in the Netherlands', Crime, Law and Social Change, 42: 163-188. 
[34] Leicht, K. T. and Fennell M. L. (1997) 'The Changing Organisation Context of Professional Work', Annual Review of Sociology, 23: 215-231.

[35] Leicht, K. T. and Fennell M. L. (2001) Professional Work, A Sociological Approach, Oxford: Blackwell Publisher, UK.

[36] Mauro, P. (1995) 'Corruption and Growth', Quarterly Journal of Economics, 110(3): 681-712.

[37] Middleton, D. J. and Levi, M. (2004) 'The Role of Solicitors in Facilitating 'Organised Crime': Situational Crime Opportunities and their Regulations', Crime, Law and Social Change, 42 (2-3): 123-161.

[38] Mishra, A., Wilson, C., \& Williams, R. (2009). Factors affecting financial performance of new and beginning farmers. Agricultural Finance Review, 69(2), 160-179.

[39] Mitchell, A. and Sikka, P. (2004) 'Accountability of the Accountancy Bodies: The Peculiarities of a British Accountancy Body', British Accounting Review, 36 (4):395-414.

[40] Mitchell, A. and Sikka, P. (2005) 'Taming the Corporations', A monograph by Association for Accountancy and Business Affairs, Basildon, UK.Accountancy Business and the Public Interest 2011

[41] Mitchell, A., Sikka, P. and Willmott, H. (1998) 'Sweeping It Under the Carpet: The Role of Accountancy Firms In Money Laundering', Accounting, Organisation and Society, 23 (5/6): 589607.

[42] Mitchell, et al (1998) 'Sweeping it Under the Carpet: The Role of Accountancy Firms in Money Laundering' Accounting Organisations and Society, 23 (5/6):589-607.

[43] Mitchell, et al (2001) 'Policing Knowledge by Invoking the Law: Critical Accounting and the Politics of Dissemination', Critical Perspectives on Accounting, 12(5): 527-555.

[44] Mitchell, et al., (2002) 'No Accounting for Tax Havens', A Monograph by Association for Accounting Business Affairs, Basildon, UK.

[45] Morris, T. and Empson, L. (1998) 'Organisation and Expertise: An Exploration of KnowledgeBased and Management Accounting and Consulting Firms', Accounting, Organisations and Society, 23 (5/6): 609-624.

[46] Neu, D., Friesen, C. and Everett, J. (2003) 'The Changing Internal Market for Ethical Discourses in the Canadian CA Profession', Accounting, Auditing and Accountability, (16 (1): 70-103.

[47] Neutze, J. and Karatnycky, A. (2007) 'Corruption, Democracy and Investment in Ukraine', The Atlantic Council of the United States Policy Paper, Washington, DC.

[48] Obayelu, A. E. (2007) 'Effects of Corruption and Economic Reforms on Economic Growth and Development: Lessons from Nigeria', paper prepared and submitted for 2007 African Economic Conference.

[49] Okike, E. (1994) 'Curious Auditing Regulations in Nigeria: A Case Study of Cultural/Political Influence on Auditing Practice', The International Journal of Accounting, 2: 139166.Accountancy Business and the Public Interest 2011

[50] Okike, E. (2004) 'Management of Crisis: The Response of the Auditing Profession in Nigeria to Challenge to its Legitimacy', Accounting, Auditing and Accountability Journal, 17 (5): 705-730.

[51] Osaghae, E. E. (1998) Crippled Giant; Nigeria since Independence, Indiana University Press.

[52] Otusanya, O. J. (2010) An Investigation of Tax Evasion, Tax Avoidance and Corruption in Nigeria, Unpublished Doctoral Thesis, University of Essex, United Kingdom.

[53] Otusanya, O. J. and Lauwo, S. (2010) 'The Role of Auditors in Nigerian Banking Crisis', Accountancy, Business and the Public Interest, 10: 159-204.

[54] Oxfam (2000) 'Tax Heaven: Releasing the Hidden Billions for Poverty Eradication', Oxfam GB Policy Paper, Online, http://www.oxfam.org.uk/what wedo/issues/debt-aid/tax-heaven.htm (accessed 25 November 2005).

[55] Pak, S. J. (2006) 'Estimates of Capital Movements from African Countries to the U.S. through Trade Mispricing', a paper presented at the Workshop on Tax, Poverty and Finance for Development, Essex Business School, University of Essex, July. 
[56] Palan, R. (2003) The Offshore World: Sovereign Markets, Virtual Places and Nomad Millionaires, London: Cornell University Press.

[57] Palan, R., Richard, M. and Chavagneux, C. (2010) Tax Havens: How Globalisation Really Works, London: Cornell University Press

[58] Peel, M. (2006) 'Nigeria-Related Financial Crime and its Link with Britain: An African Programme Report', The Royal Institute of International Affairs, Online. Available at: http://www.chathamhouse.org.uk/file/3377_nigeria1106.pdf (accessed 10 July 2008).

[59] Pope, J. (2006) 'Parliament and Anti-Corruption Legislation', in R. Stapenhurst, N. Johnston and R. Pelizzo (eds) The Role of the Parliament in Curbing Corruption, World Bank Publication.

[60] Saks, M. (1985) 'Professions and the Public Interest: The Response of the Medical Profession to Acupuncture in Nineteenth and Twentieth Century Britain', PhD Thesis: London School of Economics, University of London.

[61] Schneider, F. and Enste, D. H., (2000) 'Shadow Economies, Size, Causes and Consequences', Journal of Economic Literature, 37: 77-114.

[62] Sikka, P. (2001) 'Regulation of Accounting and Power of Capital: Some Observations', Critical Perspectives on Accounting, 12: 199-211.

[63] Sikka, P. (2003) 'The Role of Offshore Financial Centres in Globalization', Accounting Forum, 27(4): 365-399.

[64] Sikka, P. (2005) 'Corporate Tax Avoidance and Global Economic Development', A Seminar Paper presented at the International Trade and Law Institute, Online. Available at: http://visar.csuctan.edu/aaba/sikka17Jan2005.html (accessed 11 October 2006).

[65] Sikka, P. (2008a) 'Enterprise Culture and Accountancy Firms: The New Master of Universe', Accounting, Auditing and Accountability Journal, 21(2): 268-295.

[66] Sikka, P. (2008b) 'Globalization and Its Discontents: Accounting Firms Buy Limited Liability Partnership Legislation in Jersey’, Accounting, Auditing and Accountability Journal, 21 (3): 398426.

[67] Sikka, P. (2009) 'Commentary on Roy Suddaby, Yves Gendron and Helen Lam; The Organisational Context of Professionalism in Accounting', Accounting, Organisation and Society, 34(3-4): 428-432.

[68] Sikka, P. and Hampton, M. (2005) 'Tax Avoidance and Global Development: An Introduction', Accounting Forum, 29 (3): 245-248.

[69] Sikka, P. and Willmott, H. (1995) 'Illuminating the State-Profession Relationship: Accountants Acting as Department of Trade and Industry Investigators', Critical Perspectives on Accounting, 6 (4): 341-369.Accountancy Business and the Public Interest 2011

[70] Sikka, P. and Willmott, H. (1995) 'The Power of Independence: Defending and Extending the Jurisdiction of Accounting in the UK, Accounting Organisation and Society, 20 (6): 547-581.

[71] Sikka, P. And Willmott, H. (2010) 'The Dark Side of Transfer Pricing its Role in Tax Avoidance and Wealth Retentiveness', Critical Perspectives on Accounting, 21 (4): 342-356.

[72] Spronken, T. (2001) Verdenking (diss. Universiteit Maastricht) Deventer: Gouda Quint.

[73] Suddaby, R., Cooper, D. J. and Greenwood, R. (2007) 'Transnational Regulation of Professional Services: Governance Dynamics of Field Level Organisational Change', Accounting, Organisations and Society, 32: 333-362.

[74] Suddaby, R., Gendron, Y. and Lam, H. (2009) 'The Organisational Context of Professionalism in Accounting', Accounting, Organisations and Society, 34(3-4): 409-427.

[75] Tanzi, V. (2000) 'Globalization, Technology Development, and the Work of Fiscal Termites', IMF Working Paper 00/181 (Washington: International Monetary Fund. Tax Justice Network (2005) 'Tax us if you can', A TJN Briefing Paper, September, 2005.

[76] The Guardian Newspaper - Several editions.

[77] The News Newspaper - Several editions.

[78] The Punch Newspaper - Several editions. 
[79] The Sun Newspaper - Several editions.

[80] United Nations Office on Drugs and Crime (2005) 'Economic and Financial crimes: Challenges to Sustainable Development', The Eleventh United Nations Congress on Crime Prevention and Criminal Justice, Bangkok, Thailand, April, Online. Available at: http://www.unis.unvienna.org/pdf/05- 82108_E_5_pr_SFS.pdf (accessed 14 July 2008).

*Corresponding author.

E-mail address: chrischigo71@yahoo.com

\section{Appendix 1}

Dear Sir/Ma,

\section{REQUEST FOR COMPLETION OF QUESTIONNAIRE}

I am carrying out a survey titled "the challenges of professional accounting practices in Nigeria private sector with respect to financial failures in recent times.

The questions required are drafted in form of questionnaire and also purely for academic purpose and the questionnaire is anonymous as all the responses will be kept strictly confidential. You have been specifically chosen to fill this questionnaire because of your vast knowledge and experience in the construction sector.

You also considered important to achieving the objective of this study as your cooperation is therefore required in filling this questionnaire.

Please feel free to respond adequately as you spare me a few minutes of your time to respond to the questions

Thanks for your time and cooperation

\section{Section A: Respondent's Demographic Information}

This section attempts to capture the profile of the respondents, so that other data can be put in proper context. Please provide the following information about yourself by ticking $[\sqrt{ }]$ the option that best describes you.

1. Gender: Male [ ] Female [ ] ${ }^{2}$

2. AgeGroup (in years): 18- 30 [ ] $]^{1}$ 30-40 [ ] $]^{2}$ 41-50 [ ]51 and above [ ] $]^{4}$

3. Highest Level of Education: OND [ ] $]^{1}$ HND [ ] $]^{2}$ B.Sc/B.Tech/B.Eng. [ ] ${ }^{3}$ M.Sc/M.Tech/ M.Eng. [ ] ${ }^{4}$ Others (please specify) ${ }^{5}$.

4. Respondents' professional qualification: ICAN [ $]^{1}$ ACCA [ $]^{2}$ CIBN [ $]^{3}$ Others(please specify.............................. $]^{5}$ 
5. Years of working Experience: Below 10 years [ $]^{1} 11-20$ years [ $]^{2}$ 21-30 years [ ] $]^{3}$ 31-40 years [ $]^{4} 41-50[]^{5}$ Above 50 years [ $]^{6}$

\section{Section B: The Challenges of Professional Accounting Practices in Nigeria Private Sector With Respect To Financial Failures In Recent Times}

Please indicate each factor by ticking $(\sqrt{ })$ your preferred answer from alternatives provided

\begin{tabular}{|c|c|c|c|c|c|c|}
\hline $\mathrm{S} / \mathrm{N}$ & & 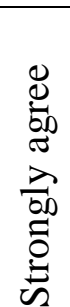 & 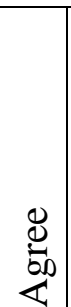 & 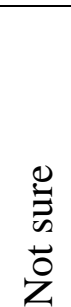 & 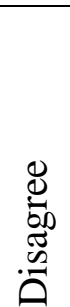 & 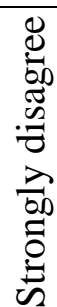 \\
\hline 1. & $\begin{array}{l}\text { The private sectors in Nigeria has been identified with high } \\
\text { quality financial reporting }\end{array}$ & & & & & \\
\hline 2. & $\begin{array}{l}\text { The business environment as obtainable in the private sector } \\
\text { allows for accountants independence in financial reporting }\end{array}$ & & & & & \\
\hline 3. & $\begin{array}{l}\text { The private sector have fallen short-off expectations in } \\
\text { financial reporting, experiencing fraud and mismanagement } \\
\text { of funds leading to their financial failure }\end{array}$ & & & & & \\
\hline 5 & $\begin{array}{l}\text { Accountants are party to some inadequacies in the financial } \\
\text { statement of private organization }\end{array}$ & & & & & \\
\hline 6 & $\begin{array}{l}\text { Poor financial reporting means false financial } \\
\text { representation of organization to the public }\end{array}$ & & & & & \\
\hline 7 & $\begin{array}{l}\text { The financial reporting of private sector is based on } \\
\text { professional accounting practices }\end{array}$ & & & & & \\
\hline 8 & $\begin{array}{l}\text { Deficiencies in the professional accounting practices is the } \\
\text { reason for poor financial reporting and disclosure of } \\
\text { corporate organizations }\end{array}$ & & & & & \\
\hline 10 & $\begin{array}{l}\text { The private sector of recent has been heavily infested with } \\
\text { corruption and inefficiency in fund management }\end{array}$ & & & & & \\
\hline 12 & $\begin{array}{l}\text { False declaration in the financial reporting of the private } \\
\text { organizations have its root in non-conformity with } \\
\text { professional accounting practices. }\end{array}$ & & & & & \\
\hline 13 & $\begin{array}{l}\text { The accountants at the helm of financial reporting are not } \\
\text { left out in the increasing financial failure of the private } \\
\text { sector }\end{array}$ & & & & & \\
\hline 14 & $\begin{array}{l}\text { The complexity of the business environment serves as a } \\
\text { threat to the accountants declaration of high quality } \\
\text { financial reporting }\end{array}$ & & & & & \\
\hline 15 & $\begin{array}{l}\text { Corrupt practices militate against the work of accountants in } \\
\text { financial report resulting in a loss of confidence in } \\
\text { professional accounting practices. }\end{array}$ & & & & & \\
\hline
\end{tabular}




\section{Appendix 2}

\section{Frequency Table}

\begin{tabular}{|c|c|c|c|c|c|}
\hline \multicolumn{6}{|c|}{ Gender } \\
\hline & & Frequency & Percent & Valid Percent & Cumulative Percent \\
\hline Valid & $\begin{array}{l}\text { Male } \\
\text { Female } \\
\text { Total }\end{array}$ & $\begin{array}{l}69 \\
51 \\
120\end{array}$ & $\begin{array}{l}57.5 \\
42.5 \\
100.0\end{array}$ & $\begin{array}{l}57.5 \\
42.5 \\
100.0\end{array}$ & $\begin{array}{l}57.5 \\
100.0\end{array}$ \\
\hline
\end{tabular}

\begin{tabular}{|ll|l|l|l|l|}
\multicolumn{2}{c|}{ Age group } \\
& & Frequency & Percent & Valid Percent & Cumulative Percent \\
\hline Valid & $18-30$ & 25 & 20.8 & 20.8 & 20.8 \\
& $30-40$ & 61 & 50.8 & 50.8 & 71.7 \\
& $41-50$ & 23 & 19.2 & 19.2 & 90.8 \\
& 51 and above & 11 & 9.2 & 9.2 & 100.0 \\
Total & 120 & 100.0 & 100.0 & \\
\hline
\end{tabular}

\section{Highest Level of Education}

\begin{tabular}{|ll|l|l|l|l|}
\hline & & & & \\
& & Frequency & Percent & Valid Percent & Cumulative Percent \\
\hline Valid & HND & 28 & 23.3 & 23.3 & 23.3 \\
B.Sc/B.Tech/B.Eng. & 66 & 55.0 & 55.0 & 78.3 \\
M.Sc/M.Tech/ M.Eng. & 26 & 21.7 & 21.7 & 100.0 \\
Total & 120 & 100.0 & 100.0 & \\
\hline
\end{tabular}

\section{Respondents' professional qualification}

\begin{tabular}{|ll|l|l|l|l|}
\hline & & & & \\
\hline Valid & ICAN & 27 & 22.5 & 22.5 & 22.5 \\
ACCA & 43 & 35.8 & 35.8 & 58.3 \\
CIBN & 17 & 14.2 & 14.2 & 72.5 \\
Others & 33 & 27.5 & 27.5 & 100.0 \\
Total & 120 & 100.0 & 100.0 & \\
\hline
\end{tabular}

Years of working Experience

\begin{tabular}{|ll|l|l|l|l|}
\hline & & & & \\
& & Frequency & Percent & Valid Percent & Cumulative Percent \\
\hline Valid & Below 10 years & 44 & 36.7 & 36.7 & 36.7 \\
& $11-20$ years & 76 & 63.3 & 63.3 & 100.0 \\
Total & 120 & 100.0 & 100.0 & \\
\hline
\end{tabular}


The private sectors in Nigeria has been identified with high quality financial reporting

\begin{tabular}{|ll|l|l|l|l|}
\hline & & & & \\
\hline Valid & Strongly agree & 26 & 21.7 & 21.7 & 21.7 \\
Agree & 38 & 31.7 & 31.7 & 53.3 \\
Not sure & 17 & 14.2 & 14.2 & 67.5 \\
Disagree & 20 & 16.7 & 16.7 & 84.2 \\
Strongly disagree & 19 & 15.8 & 15.8 & 100.0 \\
Total & 120 & 100.0 & 100.0 & \\
\hline
\end{tabular}

The business environment as obtainable in the private sector allows for accountants independence in financial reporting

\begin{tabular}{|c|c|c|c|c|c|}
\hline & & Frequency & Percent & Valid Percent & Cumulative Percent \\
\hline Valid & $\begin{array}{l}\text { Strongly agree } \\
\text { Agree } \\
\text { Not sure } \\
\text { Disagree } \\
\text { Strongly disagree } \\
\text { Total }\end{array}$ & $\begin{array}{l}8 \\
9 \\
30 \\
48 \\
25 \\
120 \\
\end{array}$ & $\begin{array}{l}6.7 \\
7.5 \\
25.0 \\
40.0 \\
20.8 \\
100.0\end{array}$ & $\begin{array}{l}6.7 \\
7.5 \\
25.0 \\
40.0 \\
20.8 \\
100.0\end{array}$ & $\begin{array}{l}6.7 \\
14.2 \\
39.2 \\
79.2 \\
100.0\end{array}$ \\
\hline
\end{tabular}

The private sectors have fallen short-off expectations in financial reporting, experiencing fraud and mismanagement of funds leading to their financial failure

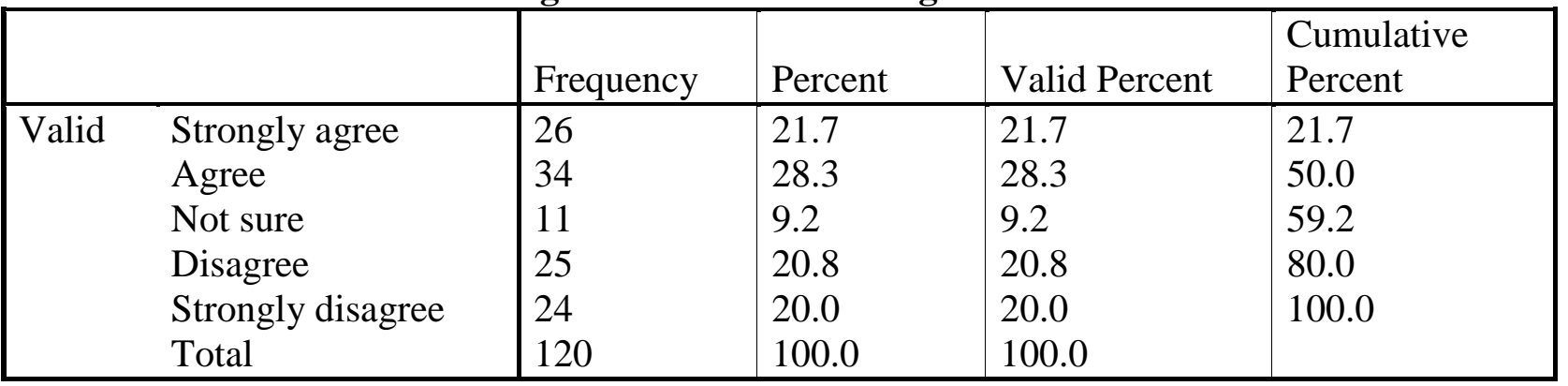

Accountants are party to some inadequacies in the financial statement of private organization

\begin{tabular}{|ll|l|l|l|l|}
\hline & & Frequency & Percent & Valid Percent & Cumulative Percent \\
\hline Valid & Strongly agree & 92 & 76.7 & 76.7 & 76.7 \\
Agree & 28 & 23.3 & 23.3 & 100.0 \\
Total & 120 & 100.0 & 100.0 & \\
\hline
\end{tabular}


Poor financial reporting means false financial representation of organization to the public

\begin{tabular}{|c|c|c|c|c|c|}
\hline & & Frequency & Percent & Valid Percent & \begin{tabular}{|l} 
Cumulative \\
Percent
\end{tabular} \\
\hline Valid & Strongly agree & 120 & 100.0 & 100.0 & 100.0 \\
\hline
\end{tabular}

The financial reporting of private sector is based on professional accounting practices

\begin{tabular}{|c|c|c|c|c|c|}
\hline & & Frequency & Percent & Valid Percent & Cumulative Percent \\
\hline Valid & $\begin{array}{l}\text { Strongly agree } \\
\text { Agree } \\
\text { Not sure } \\
\text { Disagree } \\
\text { Strongly disagree } \\
\text { Total }\end{array}$ & $\begin{array}{l}26 \\
36 \\
7 \\
33 \\
18 \\
120\end{array}$ & $\begin{array}{l}21.7 \\
30.0 \\
5.8 \\
27.5 \\
15.0 \\
100.0\end{array}$ & $\begin{array}{l}21.7 \\
30.0 \\
5.8 \\
27.5 \\
15.0 \\
100.0\end{array}$ & \begin{tabular}{|l|}
21.7 \\
51.7 \\
57.5 \\
85.0 \\
100.0
\end{tabular} \\
\hline
\end{tabular}

Deficiencies in the professional accounting practices is the reason for poor financial reporting and disclosure of corporate organizations

\begin{tabular}{|ll|l|l|l|l|}
\hline & & & & \\
Valid & Strongly agree & 40 & 33.3 & 33.3 & 33.3 \\
& Agree & 33 & 27.5 & 27.5 & 60.8 \\
& Not sure & 12 & 10.0 & 10.0 & 70.8 \\
Disagree & 26 & 21.7 & 21.7 & 92.5 \\
& Strongly disagree & 9 & 7.5 & 7.5 & 100.0 \\
Total & 120 & 100.0 & 100.0 & \\
\hline
\end{tabular}

The private sector of recent has been heavily infested with corruption and inefficiency in fund management

\begin{tabular}{|c|c|c|c|c|c|}
\hline & Frequency & Percent & Valid Percent & Cumulative Percent \\
\hline Valid & Strongly agree & 16 & 13.3 & 13.3 & 13.3 \\
\hline & Agree & 19 & 15.8 & 15.8 & 29.2 \\
\hline & Not sure & 25 & 20.8 & 20.8 & 50.0 \\
\hline & Disagree & 35 & 29.2 & 29.2 & 79.2 \\
\hline & Strongly disagree & 25 & 20.8 & 20.8 & 100.0 \\
\hline & Total & 120 & 100.0 & 100.0 & \\
\hline
\end{tabular}


False declaration in the financial reporting of the private organizations have its root in non-conformity with professional accounting practices

\begin{tabular}{|ll|l|l|l|l|}
\hline & & & & \\
& & Frequency & Percent & Valid Percent & Cumulative Percent \\
\hline Valid & Strongly agree & 37 & 30.8 & 30.8 & 30.8 \\
Agree & 62 & 51.7 & 51.7 & 82.5 \\
Not sure & 9 & 7.5 & 7.5 & 90.0 \\
Disagree & 6 & 5.0 & 5.0 & 95.0 \\
Strongly disagree & 6 & 5.0 & 5.0 & 100.0 \\
Total & 120 & 100.0 & 100.0 & \\
\hline
\end{tabular}

The accountants at the helm of financial reporting are not left out in the increasing financial failure of the private sector

\begin{tabular}{|ll|l|l|l|l|}
\hline & & & & \\
& & Frequency & Percent & Valid Percent & Cumulative Percent \\
\hline Valid & Strongly agree & 31 & 25.8 & 25.8 & 25.8 \\
Agree & 51 & 42.5 & 42.5 & 68.3 \\
Not sure & 6 & 5.0 & 5.0 & 73.3 \\
Disagree & 13 & 10.8 & 10.8 & 84.2 \\
Strongly disagree & 19 & 15.8 & 15.8 & 100.0 \\
Total & 120 & 100.0 & 100.0 & \\
\hline
\end{tabular}

The complexity of the business environment serves as a threat to the accountants declaration of high quality financial reporting

\begin{tabular}{|c|c|c|c|c|c|}
\hline & & Frequency & Percent & Valid Percent & Cumulative Percent \\
\hline Valid & $\begin{array}{l}\text { Strongly agree } \\
\text { Agree } \\
\text { Not sure } \\
\text { Disagree } \\
\text { Strongly disagree } \\
\text { Total }\end{array}$ & $\begin{array}{l}58 \\
44 \\
7 \\
6 \\
5 \\
120 \\
\end{array}$ & $\begin{array}{l}48.3 \\
36.7 \\
5.8 \\
5.0 \\
4.2 \\
100.0 \\
\end{array}$ & $\begin{array}{l}48.3 \\
36.7 \\
5.8 \\
5.0 \\
4.2 \\
100.0 \\
\end{array}$ & $\begin{array}{l}48.3 \\
85.0 \\
90.8 \\
95.8 \\
100.0\end{array}$ \\
\hline
\end{tabular}

Corrupt practices militate against the work of accountants in financial report resulting in a loss of confidence in professional accounting practices

\begin{tabular}{|ll|l|l|l|l|}
\hline & & & & \\
& & Frequency & Percent & Valid Percent & Cumulative Percent \\
\hline Valid & Strongly agree & 94 & 78.3 & 78.3 & 78.3 \\
Agree & 26 & 21.7 & 21.7 & 100.0 \\
Total & 120 & 100.0 & 100.0 & \\
\hline
\end{tabular}


Relevance, understandability, reliability, completeness, objectivity, timeliness and comparability are most important in the context of financial reporting information of private sector

\begin{tabular}{|l|l|l|l|l|}
\hline & & & \\
& Frequency & Percent & Valid Percent & Cumulative Percent \\
\hline Valid Strongly agree & 120 & 100.0 & 100.0 & 100.0 \\
\hline
\end{tabular}

A business environment riddled with corruptible practices poses a lot of challenges to accountant conforming to professional accounting practices in financial reporting

\begin{tabular}{|ll|l|l|l|l|}
\hline & & Frequency & Percent & Valid Percent & Cumulative Percent \\
\hline Valid & Strongly agree & 53 & 44.2 & 44.2 & 44.2 \\
& Agree & 52 & 43.3 & 43.3 & 87.5 \\
Not sure & 5 & 4.2 & 4.2 & 91.7 \\
Disagree & 10 & 8.3 & 8.3 & 100.0 \\
Total & 120 & 100.0 & 100.0 & \\
\hline
\end{tabular}

Transparency, accountability, honesty, neutrality and truth, fairness, professional independence reflect in private sector financial reporting

\begin{tabular}{|c|c|c|c|c|c|}
\hline & & Frequency & Percent & Valid Percent & Cumulative Percent \\
\hline Valid & $\begin{array}{l}\text { Strongly agree } \\
\text { Agree } \\
\text { Not sure } \\
\text { Disagree } \\
\text { Strongly disagree } \\
\text { Total }\end{array}$ & $\begin{array}{l}15 \\
30 \\
20 \\
30 \\
25 \\
120\end{array}$ & $\begin{array}{l}12.5 \\
25.0 \\
16.7 \\
25.0 \\
20.8 \\
100.0\end{array}$ & $\begin{array}{l}12.5 \\
25.0 \\
16.7 \\
25.0 \\
20.8 \\
100.0\end{array}$ & $\begin{array}{l}12.5 \\
37.5 \\
54.2 \\
79.2 \\
100.0\end{array}$ \\
\hline
\end{tabular}

